\title{
Evaluating Asthma Mobile Apps to Improve Asthma Self-Management: User Ratings and Sentiment Analysis of Publicly Available Apps
}

Marlene Camacho-Rivera ${ }^{1}$, BSc, MPH, MSc, SCD; Huy Vo², PhD; Xueqi Huang ${ }^{2}$, MSc; Julia Lau ${ }^{2}$, BSc; Adeola Lawal $^{3}$, BSc; Akira Kawaguchi ${ }^{2}$, PhD

\footnotetext{
${ }^{1}$ Department of Community Health Sciences, SUNY Downstate Health Sciences University, Brooklyn, NY, United States

${ }^{2}$ Department of Computer Science, Grove School of Engineering, City College of New York, New York, NY, United States

${ }^{3}$ Department of Community Health and Social Medicine, CUNY School of Medicine, New York, NY, United States
}

\section{Corresponding Author:}

Marlene Camacho-Rivera, BSc, MPH, MSc, SCD

Department of Community Health Sciences

SUNY Downstate Health Sciences University

450 Clarkson Avenue, MSC 43

Brooklyn, NY, 11203

United States

Phone: 17182704386

Email: marlene.camacho-rivera@downstate.edu

\section{Abstract}

Background: The development and use of mobile health (mHealth) apps for asthma management have risen dramatically over the past two decades. Asthma apps vary widely in their content and features; however, prior research has rarely examined preferences of users of publicly available apps.

Objective: The goals of this study were to provide a descriptive overview of asthma mobile apps that are publicly available and to assess the usability of asthma apps currently available on the market to identify content and features of apps associated with positive and negative user ratings.

Methods: Reviews were collected on June 23, 2020, and included publicly posted reviews until June 21, 2020. To characterize features associated with high or low app ratings, we first dichotomized the average user rating of the asthma app into 2 categories: a high average rating and a low average rating. Asthma apps with average ratings of 4 and above were categorized as having a high average rating. Asthma apps with average ratings of less than 4 were categorized as having a low average rating. For the sentiment analysis, we modeled both 2-word (bi-gram) and 3-word (tri-gram) phrases which commonly appeared across highly rated and lowly rated apps.

Results: Of the 10 apps that met the inclusion criteria, a total of 373 reviews were examined across all apps. Among apps reviewed, 53.4\% (199/373) received high ratings (average ratings of 4 or 5) and 47.2\% (176/373) received low ratings (average ratings of 3 or less). The number of ratings across all apps ranged from 188 (AsthmaMD) to 10 (My Asthma App); 30\% (3/10) of apps were available on both Android and iOS. From the sentiment analysis, key features of asthma management that were common among highly rated apps included the tracking of peak flow readings $(\mathrm{n}=48)$, asthma symptom monitoring $(\mathrm{n}=11)$, and action plans $(\mathrm{n}=10)$. Key features related to functionality that were common among highly rated apps included ease of use $(\mathrm{n}=5)$. Users most commonly reported loss of data $(\mathrm{n}=14)$ and crashing of app $(\mathrm{n}=12)$ as functionality issues among poorly rated asthma apps.

Conclusions: Our study results demonstrate that asthma app quality, maintenance, and updates vary widely across apps and platforms. These findings may call into question the long-term engagement with asthma apps, a crucial factor for determining their potential to improve asthma self-management and asthma clinical outcomes.

(JMIR Mhealth Uhealth 2020;8(10):e15076) doi: $\underline{10.2196 / 15076}$

\section{KEYWORDS}

mHealth; asthma apps; sentiment analysis; user ratings; smartphone; mobile phone 


\section{Introduction}

\section{Background}

Asthma is the leading chronic disease in children and adolescents and one of the most common among adults, with more than 25 million Americans impacted [1]. Nationally, asthma accounts for 11 million doctor's office visits, 439,435 discharges from hospital inpatient care, and 1.7 million emergency department visits each year [2]. Further, economic costs associated with asthma are significant, both for the United States and for asthmatics and their families. From 2008 to 2013, the annual economic cost of asthma was more than US $\$ 81.9$ billion, including medical costs and loss of work and school days: US $\$ 3$ billion in losses due to missed work and school days, US \$29 billion due to asthma-related mortality, and US $\$ 50.3$ billion in medical costs [2].

Many factors combine to contribute to poor asthma rates and worsen outcomes. Provider practice behaviors, suboptimal access to health care, lack of patient knowledge regarding proper medication use, and patients' difficulty adhering to medical regimens contribute to poor asthma outcomes [3-8]. With appropriate medical care including education, patients can achieve asthma control; however, there are competing challenges to providing effective patient education, such as time constraints and prioritizing other issues above asthma education [9].

Mobile health apps and devices to monitor and track health-related questions are a rapidly growing field within the public health, data science, and technology sectors [10-16], and offer potential opportunities to address some of the barriers to patient asthma education [17-20].

However, promotion of new technologies is predicated on the hypothesis that enabling people to quantify their own behaviors will drive health behavior change through contextualization and goal setting [21]. Mobile apps (configured to work independently or with wearable devices) can be used to record and track health-related behaviors, provide tailored education, and send reminders and prompts. Nationally, approximately $80 \%$ of US adults own a smartphone and close to $60 \%$ of smartphone owners also report installing one or more health apps onto their smartphones [22,23].

In recent years, there has been a proliferation of new mobile apps for the self-assessment and self-management of asthma
[24,25]. However, uptake of asthma apps has been sparse, despite evidence of their efficacy in impacting asthma outcomes [26]. Results from randomized controlled studies show that use of mobile health apps improves asthma symptoms and medication compliance, which should, in turn, reduce emergency department visits and hospital admissions [27-29]. To our knowledge, there has not been a comprehensive review of asthma apps which considers user ratings, features, and reviews as a tool to identify potential barriers and facilitators of app use among individuals self-managing asthma.

\section{Objectives}

The aims of this study were (1) to provide a descriptive overview of asthma mobile apps that are publicly available and (2) to assess the usability of asthma apps currently available on the market to identify content and features of apps associated with positive and negative user ratings.

\section{Methods}

\section{Asthma App Selection}

To examine the average user rating and reviews for asthma apps, the following inclusion criteria were applied for our search: apps must be available for download on Android or iOS platforms, written in English, available within the United States, able to be downloaded onto a smartphone or tablet, and had at least one update within the last 5 years. Apps must also have a primary focus on asthma, with respect to either asthma education or asthma self-management. Because of the potential for bias in ratings due to small sample size, only apps that had more than 10 written reviews were included. Apps were not excluded based on cost for use or intended audience. We started with a comprehensive list of apps that strictly matched our inclusion criteria. The list was expanded by using the following keywords commonly associated with asthma education or asthma management to identify additional asthma apps: asthma management, asthma game, asthma quiz, peakflow, and asthma education. All apps were evaluated by the research team based on inclusion criteria; of the 51 apps initially reviewed, 29 apps had been updated in the last 5 years. Of the 29 apps recently updated, 19 were excluded based on having less than 10 written reviews available. The final list of 10 apps included in the analysis is presented in Table 1. 
Table 1. List of asthma mobile apps included in analysis.

\begin{tabular}{|c|c|c|c|c|c|c|}
\hline Name & Developer & Android & iOS & Last update & $\begin{array}{l}\text { Update } \\
\text { times }\end{array}$ & Category \\
\hline My Asthma App & Asthma and Respiratory Foundation NZ & $\mathrm{N} / \mathrm{A}^{\mathrm{a}}$ & $\mathrm{X}$ & May 5, 2019 & 6 & Education \\
\hline Propeller & Reciprocal Labs & $\mathrm{X}$ & N/A & March 28, 2019 & 25 & Management \\
\hline SaniQ Asthma & Qurasoft GmbH & $\mathrm{X}$ & $X$ & March 19, 2019 & 25 & Management \\
\hline Asthma Tracker & Kantonsspital Baselland & N/A & $\mathrm{X}$ & March 13, 2019 & 12 & Management \\
\hline AirCasting & HabitatMap & N/A & $\mathrm{X}$ & March 7, 2019 & N/A & Environmental Data \\
\hline Peak Flow & Ben Hills & $X$ & N/A & April 26, 2018 & N/A & Management \\
\hline My Asthma Pal & Children's Medical Center of Dallas & $\mathrm{X}$ & $\mathrm{X}$ & March 7, 2019 & 6 & Management \\
\hline asthmaTrack & dangerDown LLC & N/A & $\mathrm{X}$ & January 18, 2018 & 28 & Management \\
\hline Breathcount asthma control & Segfoltas & $X$ & N/A & January 9, 2017 & N/A & Management \\
\hline AsthmaMD & AsthmaMD, Inc. & $X$ & $\mathrm{X}$ & March 10, 2017 & 21 & Management \\
\hline
\end{tabular}

${ }^{\mathrm{a}} \mathrm{N} / \mathrm{A}$ : Not available

\section{User Ratings}

To identify specific sentiments within language characteristics of user reviews that are associated with high or low app ratings, we first dichotomized the average user rating of the asthma app into 2 categories: a high average rating and a low average rating. Asthma apps with average ratings of 4 and above were categorized as having a high average rating. Asthma apps with average ratings of less than 4 were categorized as having a low average rating.

\section{Sentiment Analysis of User Reviews: N-Gram models}

An $N$-gram is a contiguous sequence of $\mathrm{n}$ items from a piece of article, sentence, or speech. An $N$-gram model is a probabilistic language model for predicting the next item given the sequence of $(n-1)$-gram, which simulates characteristics of the language used in a certain corpus. Its simplicity and scalability enable its application in sentiment analysis of the reviews [30]. For this analysis, we modeled both 2 -word (bi-gram) and 3-word (tri-gram) phrases that commonly appeared across highly rated and lowly rated reviews. Because of the limited number of reviews, the tri-gram model did not yield expressive results, as it identified the same tri-gram peak flow meter in both the good and bad reviews. The bi-grams extracted from the model showed distinct patterns in good reviews and bad reviews. As such, results from bi-gram models for highly rated reviews and lowly rated reviews are discussed in the next section. We removed the stop words in the preprocessing step, and separated the reviews into good reviews (ratings >3) and bad reviews (ratings $\leq 3$ ). Reviews were collected on June 23, 2020, and contain reviews from January 08,2010 , to June 21,2020 . Of the 10 apps that met the inclusion criteria, a total of 373 reviews were examined across all apps.

\section{Results}

\section{Asthma App Descriptive Results}

Of the 10 apps included in the analysis, 6 were available at no cost to users and 4 apps were available for purchase, with a maximum cost of US $\$ 2.99 ; 50 \%$ of apps $(n=5)$ were updated in the past 2 years.

As shown in Figures 1-3, among apps reviewed, 53.4\% (199/373) received high ratings (average ratings of 4 or 5$)$ and $47.2 \%(176 / 373)$ received low ratings (average ratings of $\leq 3$ ). The number of ratings across all apps ranged from 188 (AsthmaMD) to 10 (My Asthma App). Three of the apps were available on both Android and iOS platforms.

Stream graph of the number of review counts from 2010 to 2020 is shown in Figure 1. The number of reviews for each app is displayed in a distinct color to visually track the change in number of reviews over time. The height of the colored area suggests the number of reviews an app gets in the year. The width of the colored area suggests the total number of reviews an app gets over the years. As shown in Figure 1, the dominant app is AsthmaMD, which reached a peak number of reviews during 2012 to 2014. 
Figure 1. Stream graph of the review counts for asthma apps from 2010 to 2020.

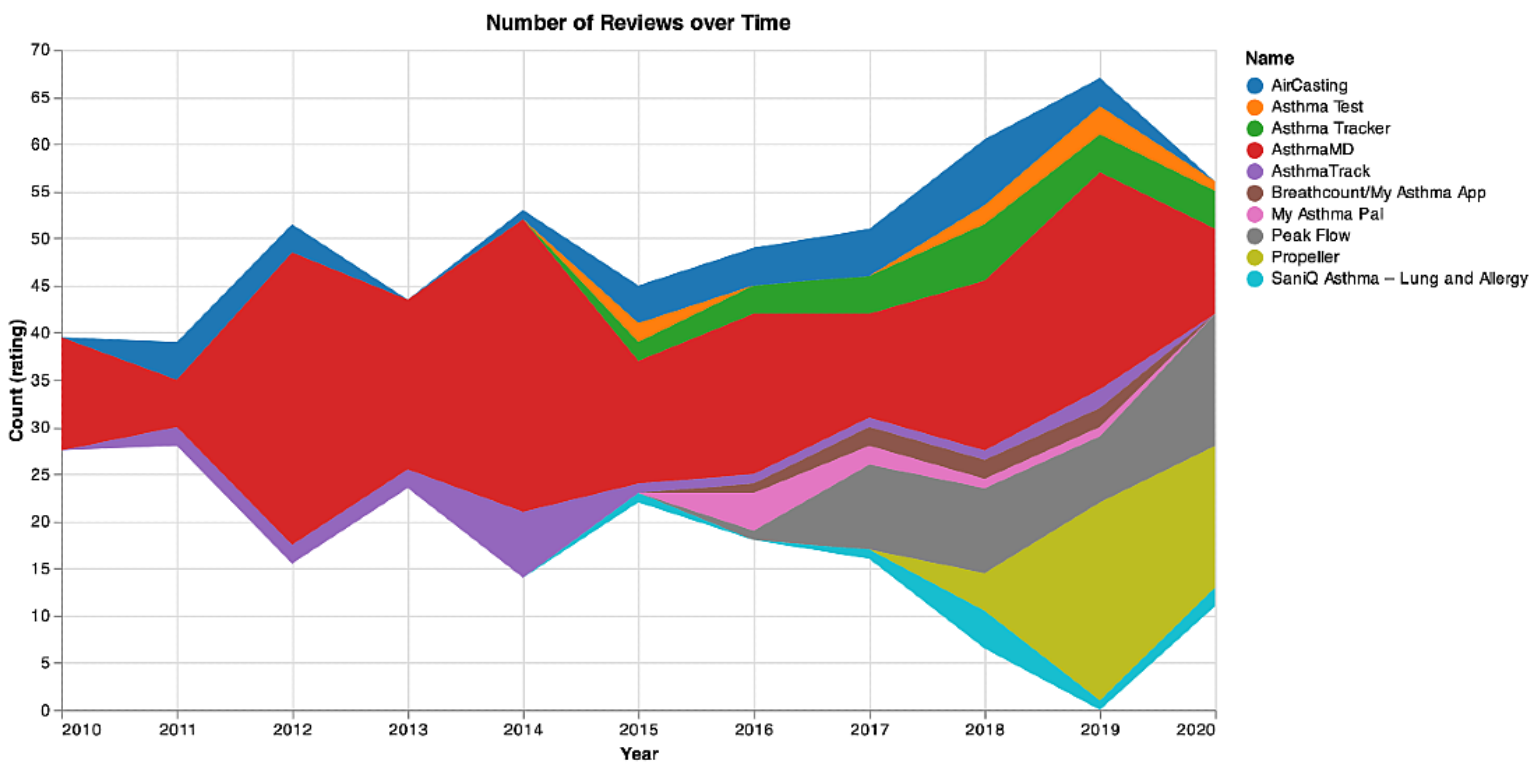

Figure 2. Bi-gram results of functionalities of highly rated asthma mobile apps.

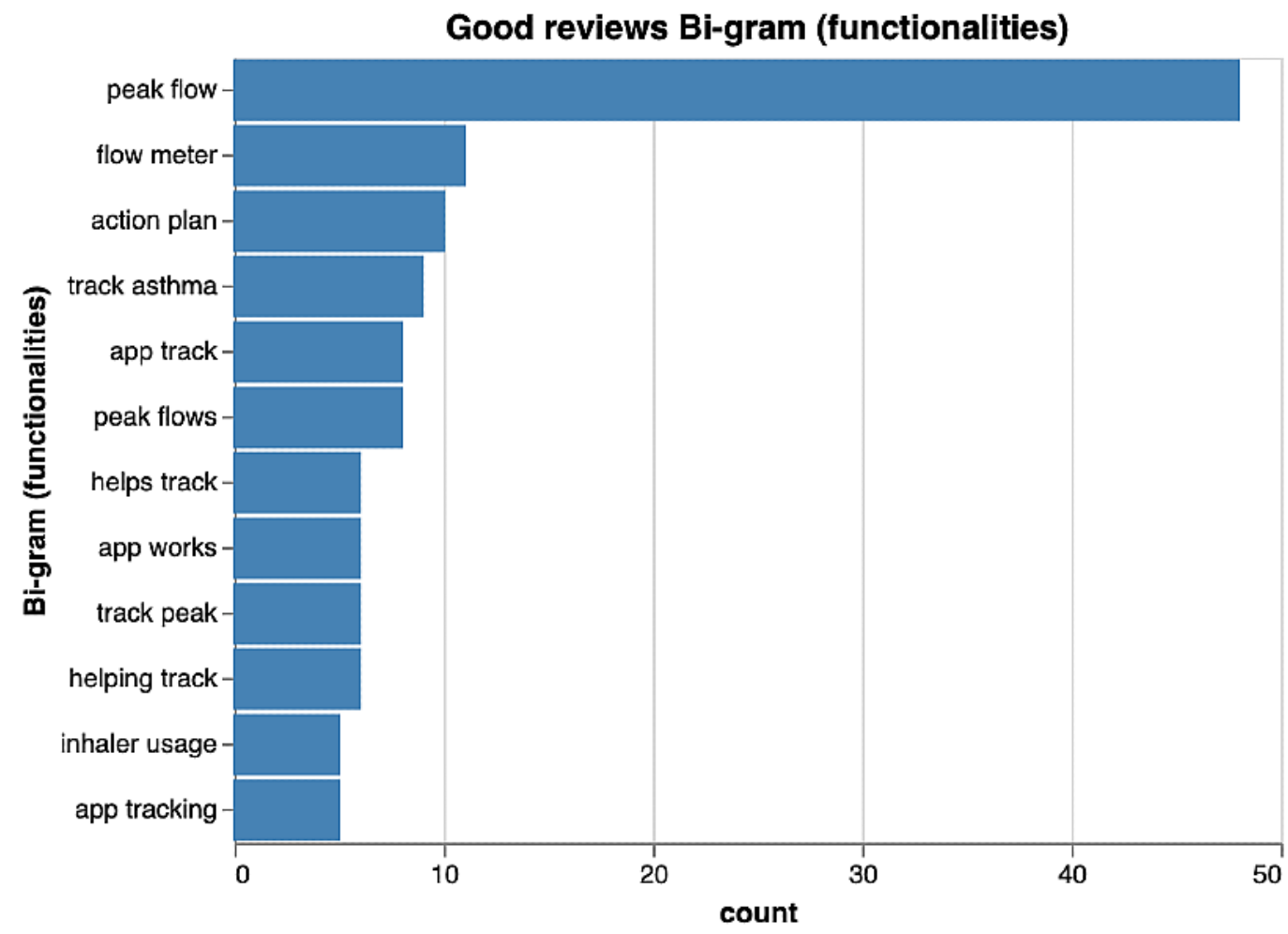


Figure 3. Bi-gram results of features of highly rated asthma mobile apps.

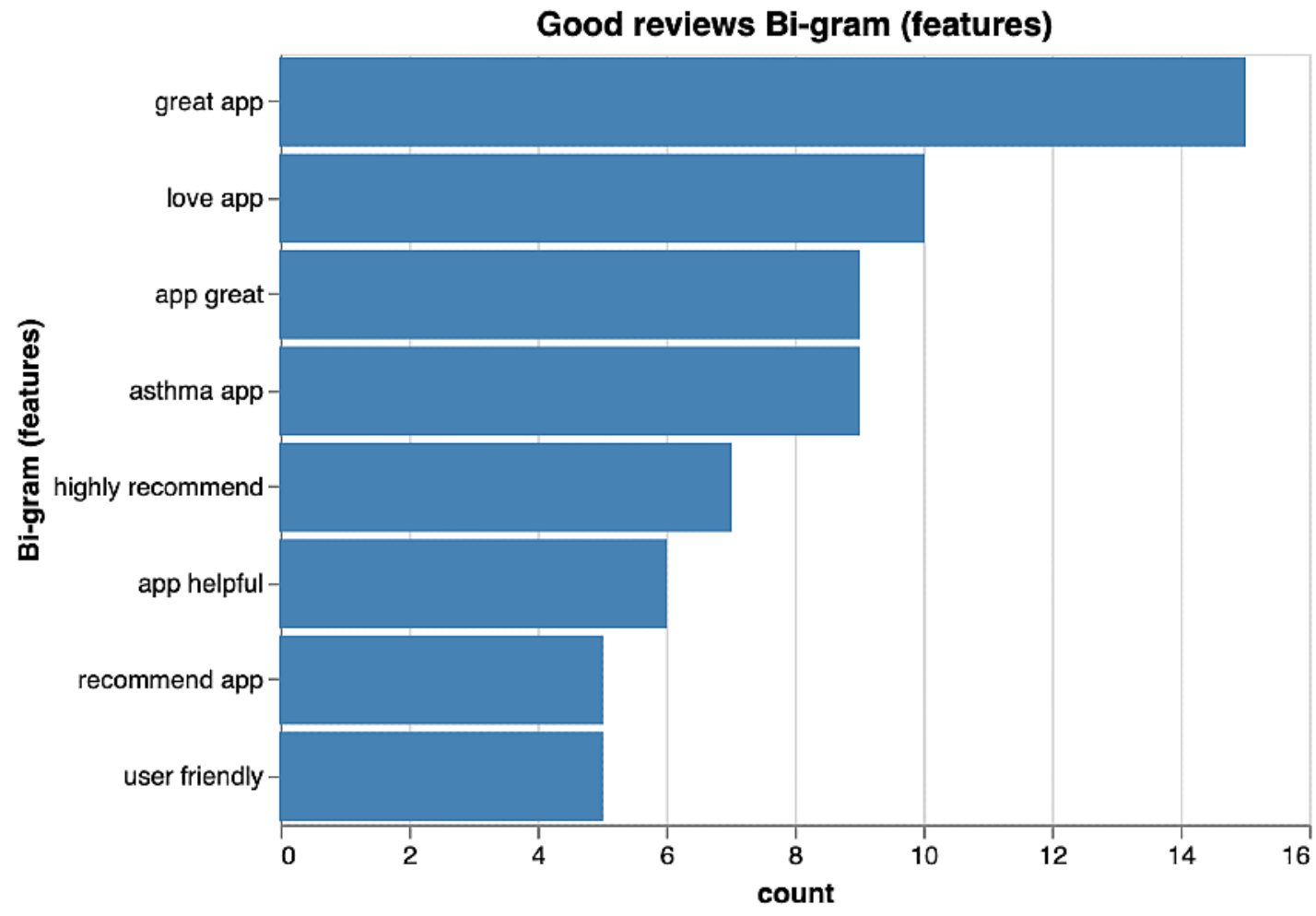

\section{Sentiment Analysis of User Reviews}

Distinct patterns of language were observed when comparing highly rated and poorly rated apps. Among the highly rated reviews, bi-grams emerged with respect to features as well as functionality of the app. Figures 2 and 3 depict the frequencies of the most commonly occurring bi-grams among highly rated apps. Several key features of asthma management that were common among highly rated apps included the tracking of peak flow readings ( $\mathrm{n}=48)$, asthma symptom monitoring $(\mathrm{n}=11)$, and action plans $(\mathrm{n}=10)$. Key features related to functionality that were common among highly rated apps included ease of use $(\mathrm{n}=5)$, as illustrated in Figure 2.

Among poorly rated asthma apps, bi-grams (Figures 4 and 5) predominantly focused on functionality issues encountered by users (Figure 4). The functionality keywords that had the most common occurrences in bad reviews were create account $(n=8)$, lost data $(n=6)$, open app $(n=5)$. By identifying the most important words (or keywords) in negative reviews through the term frequency-inverse document frequency measure in Figure 6 , we concluded that users most commonly reported loss of data $(\mathrm{n}=14)$ and crashing of app $(\mathrm{n}=12)$ as functionality issues among poorly rated asthma apps. 
Figure 4. Bi-gram results of functionalities of poorly rated asthma mobile apps.

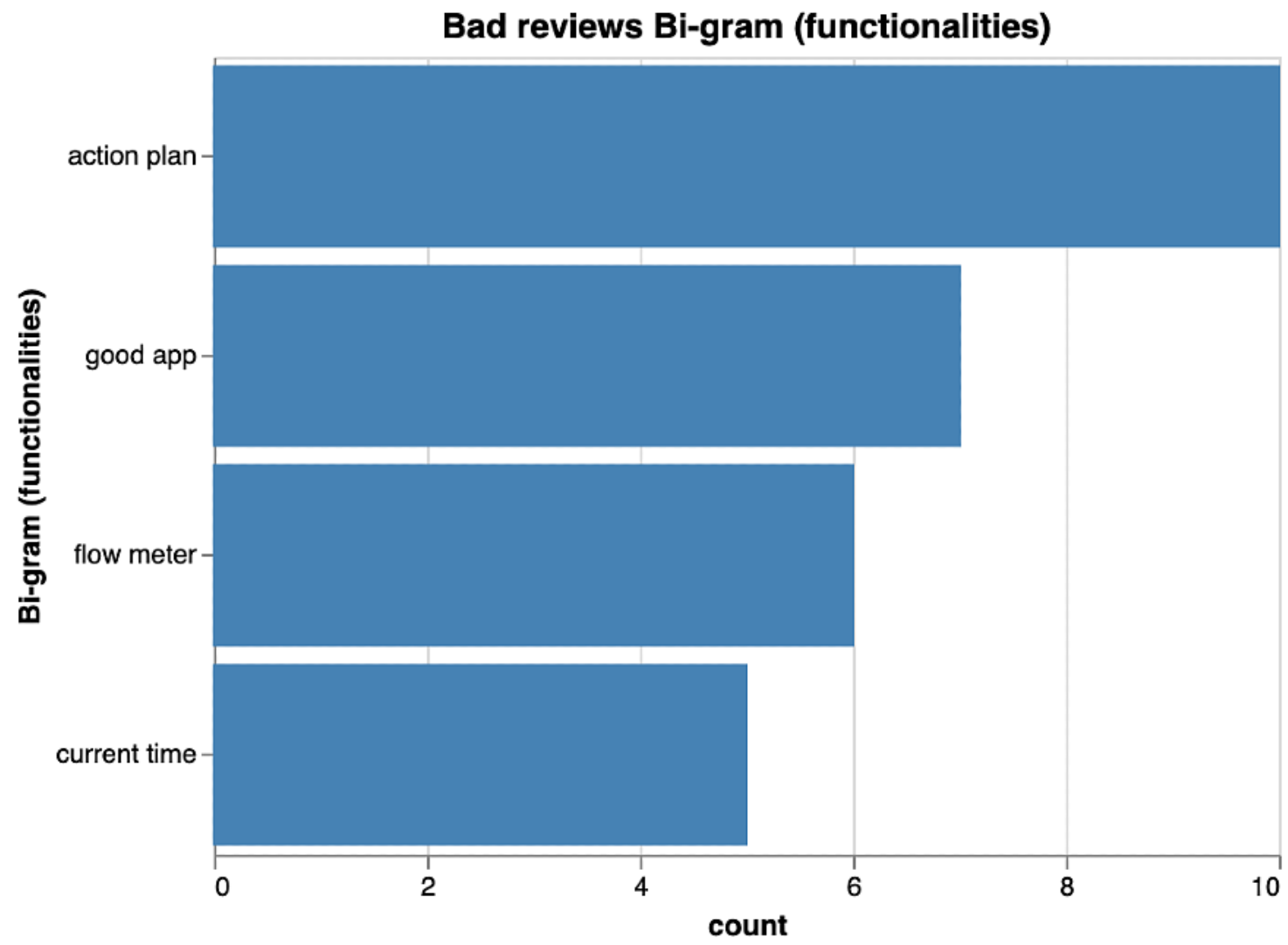

Figure 5. Bi-gram results of features of poorly rated asthma apps.

Bad reviews Bi-gram (features)

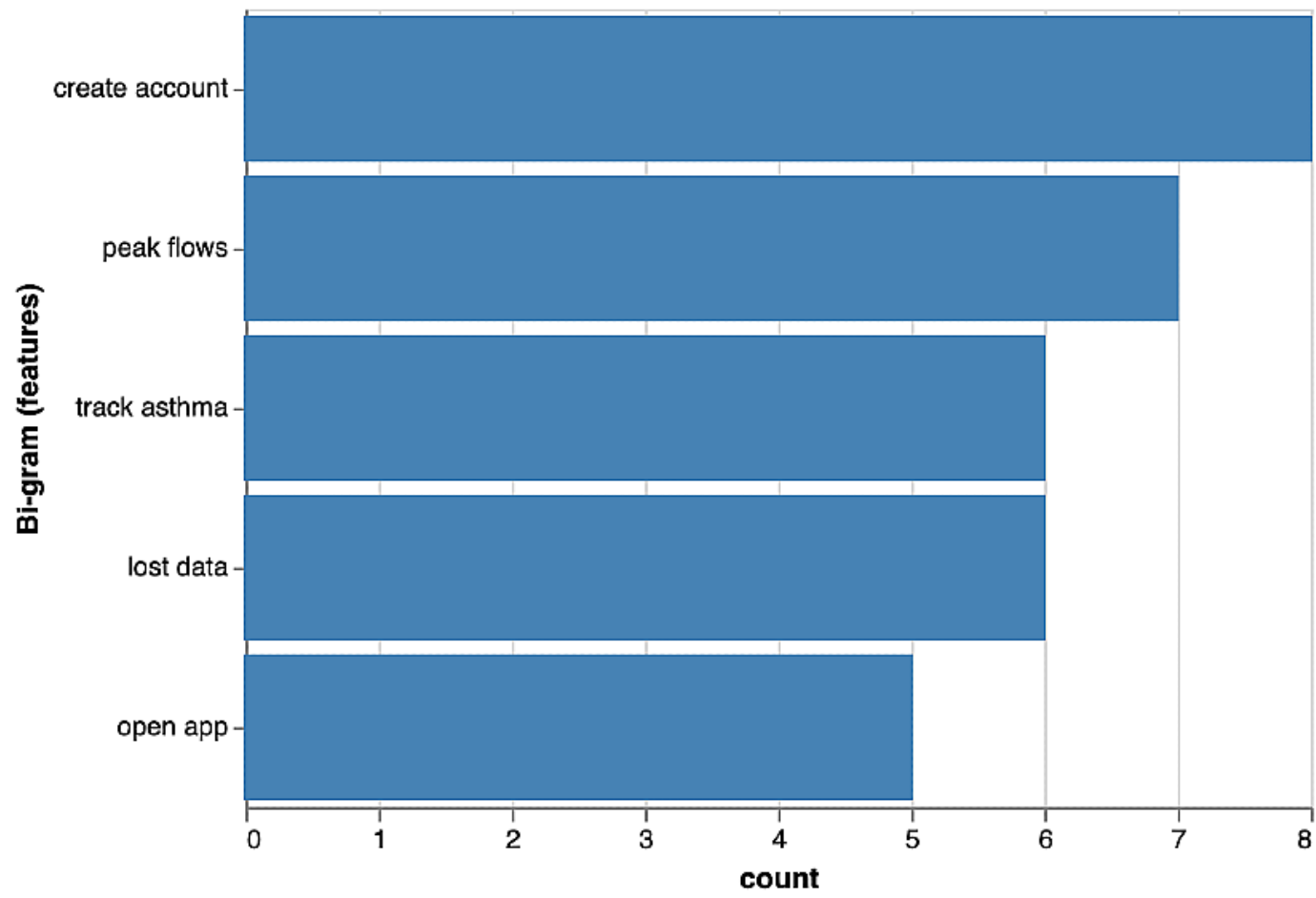


Figure 6. Top words in reviews of poorly rated asthma apps.

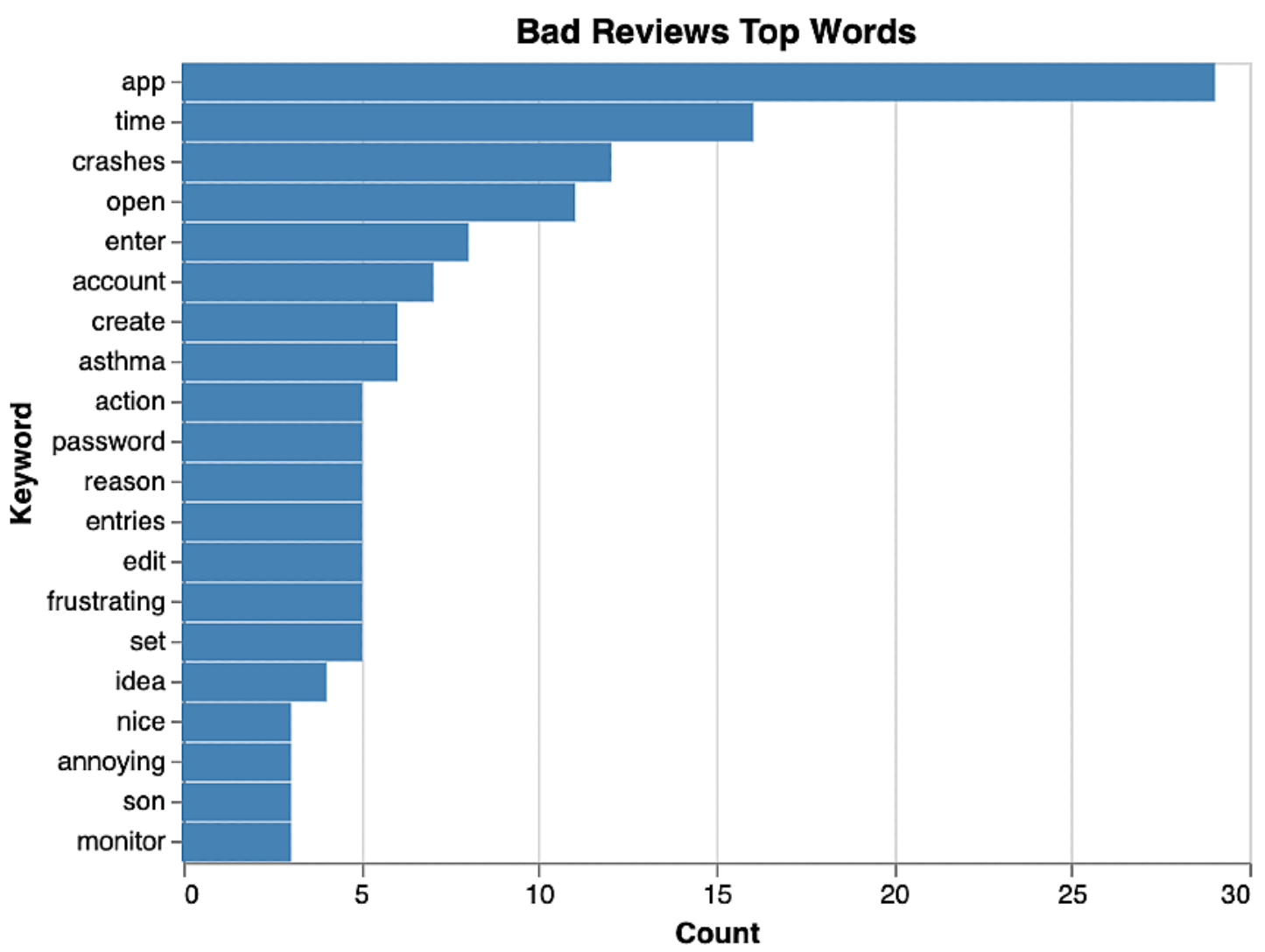

\section{Discussion}

\section{Principal Results}

This study analyzed ratings and features of publicly available asthma apps to identify user preferences. Our descriptive results confirmed those of prior studies which observed the limited availability of publicly available, up-to-date asthma apps on the market [26]. In terms of available functions, we observed that most asthma apps offered functions associated with several recommendations of effective self-management including asthma education, peak flow monitoring, and an action plan [31]. Consistent with prior reviews of asthma apps, our results confirmed that asthma apps offered either education or management, with few offering a combination of both [25].

Furthermore, our study results demonstrated that asthma app quality varied widely, ranging anywhere from an average user rating of 1.5 out of 5 to 5 out of 5 . It also appeared that individual asthma apps varied in their user rating between Android and iOS platforms. These findings may call into question the long-term engagement with asthma apps, a crucial factor for determining their value [32,33]. In other domains such as diabetes self-management, researchers have observed that long-term engagement of app users is generally limited [34]. However, chronic diseases such as asthma require long-term self-management.

\section{Recommendations for App Features and Functions}

With the $N$-grams model, we were able to capture several characteristics related to features and functionality that users like or dislike about the apps; for example, peak flow and action plan were frequently mentioned among features, whereas easy to use and doesn't work were frequently mentioned around functionality. Previous studies of asthma apps confirmed peak flow tracking, symptom tracking, and medication tracking as some of the most common functions in highly rated apps [25]. Additional function recommendations which were not captured in our sentiment analysis but have been identified in previous studies of asthma apps include medical appointment tracking, health snapshots, and clinical asthma questionnaires [20,26,35]. Additional categories which have been identified through formative research of specific asthma apps include the incorporation of notification features such as those related to medication reminders, medical appointment reminders, and peak flow reading reminders [36-40].

One potential way to improve long-term engagement, which has been successfully applied to physical activity, is interactions with virtual coaches $[41,42]$. Thus, developers of upcoming asthma apps might consider the implementation of virtual coaches to enhance long-term engagement. Another potential method of improving long-term engagement, in particular among children and adolescents with asthma, could be through gamification and use of contingent rewards [43-45]. Lastly, application of behavior change techniques including specific goal setting, provision of performance feedback, and barrier identification may also improve acceptability and long-term engagement with asthma apps [46-48].

\section{Limitations}

Our study did have several limitations, which should be considered when interpreting its findings. The popularity of an asthma app may not yield information regarding the quality of 
the asthma content presented in the app with respect to the clinical or scientific literature. Prior studies have observed variability in the quality of asthma information with respect to its consistency with National Asthma Education and Prevention Program guidelines [3]. Future studies should examine the concordance between asthma education and asthma management clinical tools within popular asthma apps.

Limitations of sentiment analysis include its sensitivity to review content; as such, user ratings may not always correspond to descriptive reviewer feedback. Further, displays of reviews were limited to downloads with a minimum threshold of 10 reviews. However, sentiment analysis has been increasingly applied across a variety of health outcomes [49-52]. Finally, this study did not include assessment of apps using a validated instrument (eg, Mobile Application Rating Scale). However, this type of analysis was conducted in a previous review of asthma apps [25].

\section{Conclusions}

Our study extends previous research in this field by focusing on the experiences and reviews of asthmatics' interactions with publicly available asthma apps. Our study results have several implications with respect to informing the development of asthma mobile apps and their recommendation for clinical use. As use of asthma apps have been found to have an impact on several clinical outcomes, including but not limited to control, quality of life, medication adherence, and patient-reported outcomes, improvements to asthma apps should include a focus on user-centered design and experiences. Combining big-data analytic approaches with qualitative data from users may yield additional insights to improve usability and long-term engagement with asthma apps. Further, collaborations between asthma app developers, clinicians, and researchers should include considerations regarding data security, privacy features, and sharing of personal health information which would also increase patient and provider confidence regarding recommending the use of asthma mobile apps to improve asthma self-management.

\section{Acknowledgments}

This study was supported by a City University of New York Interdisciplinary Research Grant to MC-R and AK. MC-R is supported by TRANSPORT - The Translational Program of Health Disparities Research Training (5S21MD012474-02).

\section{Authors' Contributions}

MC-R and HV led the drafting of the manuscript and supervised the process. HV, XH, and JL contributed to the data analysis. MC-R, AL, and AK contributed to the discussion of data.

\section{Conflicts of Interest}

None declared.

\section{References}

1. Centers for Disease Control and Prevention. Asthma Surveillance Data. Atlanta, GA: Centers for Disease Control and Prevention URL: https://www.cdc.gov/asthma/asthmadata.htm [accessed 2020-07-10]

2. Nurmagambetov T, Kuwahara R, Garbe P. The Economic Burden of Asthma in the United States, 2008-2013. Ann Am Thorac Soc 2018 Mar;15(3):348-356. [doi: 10.1513/AnnalsATS.201703-259OC] [Medline: 29323930]

3. Fletcher MJ, Tsiligianni I, Kocks JWH, Cave A, Chunhua C, Sousa JCD, et al. Improving primary care management of asthma: do we know what really works? NPJ Prim Care Respir Med 2020 Jun 17;30(1):29 [FREE Full text] [doi: 10.1038/s41533-020-0184-0] [Medline: 32555169]

4. Madhok N, Kipperman S, Tom C, Sin S, Rastogi D. Parental Perception and Knowledge of Asthma Severity and Management of Athmatic Children in the Bronx. Journal of Allergy and Clinical Immunology 2009 Feb;123(2):S161. [doi: 10.1016/j.jaci.2008.12.606]

5. McQuaid EL. Barriers to medication adherence in asthma: The importance of culture and context. Ann Allergy Asthma Immunol 2018 Jul;121(1):37-42. [doi: 10.1016/j.anai.2018.03.024] [Medline: 29580846]

6. McQuaid EL, Everhart RS, Seifer R, Kopel SJ, Mitchell DK, Klein RB, et al. Medication adherence among Latino and non-Latino white children with asthma. Pediatrics 2012 Jun;129(6):e1404-e1410 [FREE Full text] [doi: 10.1542/peds.2011-1391] [Medline: 22566417]

7. Tackett AP, Farrow M, Kopel SJ, Coutinho MT, Koinis-Mitchell D, McQuaid EL. Racial/ethnic differences in pediatric asthma management: the importance of asthma knowledge, symptom assessment, and family-provider collaboration. $\mathrm{J}$ Asthma 2020 Jul 01:1-12. [doi: 10.1080/02770903.2020.1784191] [Medline: $\underline{32546119}$ ]

8. Everhart RS, Koinis Mitchell D, Friedman D, Kopel S, Canino G, Fritz G, et al. Pediatric asthma management within Latino and non-Latino White families. Fam Syst Health 2014 Jun;32(2):167-175. [doi: 10.1037/fsh0000005] [Medline: 24611719]

9. Singh S, Surani S, McGuinness S, Eudicone J, Gilbert I, Subramanian S. Current practice patterns, challenges, and educational needs of asthma care providers in the United States. J Asthma 2020 May 19:1-10. [doi: 10.1080/02770903.2020.1761980] [Medline: $\underline{32336241]}$ 
10. Indraratna P, Tardo D, Yu J, Delbaere K, Brodie M, Lovell N, et al. Mobile Phone Technologies in the Management of Ischemic Heart Disease, Heart Failure, and Hypertension: Systematic Review and Meta-Analysis. JMIR Mhealth Uhealth $2020 \mathrm{Jul}$ 06;8(7):e16695 [FREE Full text] [doi: 10.2196/16695] [Medline: $\underline{\text { 32628615] }}$

11. Tully L, Burls A, Sorensen J, El-Moslemany R, O'Malley G. Mobile Health for Pediatric Weight Management: Systematic Scoping Review. JMIR Mhealth Uhealth 2020 Jun 03;8(6):e16214 [FREE Full text] [doi: 10.2196/16214] [Medline: $\underline{32490849]}$

12. Koepp J, Baron MV, Hernandes Martins PR, Brandenburg C, Kira ATF, Trindade VD, et al. The Quality of Mobile Apps Used for the Identification of Pressure Ulcers in Adults: Systematic Survey and Review of Apps in App Stores. JMIR Mhealth Uhealth 2020 Jun 16;8(6):e14266 [FREE Full text] [doi: $\underline{10.2196 / 14266}$ ] [Medline: $\underline{32470916}$ ]

13. de Cock C, van Velthoven M, Milne-Ives M, Mooney M, Meinert E. Use of Apps to Promote Childhood Vaccination: Systematic Review. JMIR Mhealth Uhealth 2020 May 18;8(5):e17371 [FREE Full text] [doi: 10.2196/17371] [Medline: $\underline{32421684]}$

14. Lau N, O'Daffer A, Colt S, Yi-Frazier JP, Palermo TM, McCauley E, et al. Android and iPhone Mobile Apps for Psychosocial Wellness and Stress Management: Systematic Search in App Stores and Literature Review. JMIR Mhealth Uhealth 2020 May 22;8(5):e17798 [FREE Full text] [doi: 10.2196/17798] [Medline: 32357125]

15. Lecomte T, Potvin S, Corbière M, Guay S, Samson C, Cloutier B, et al. Mobile Apps for Mental Health Issues: Meta-Review of Meta-Analyses. JMIR Mhealth Uhealth 2020 May 29;8(5):e17458 [FREE Full text] [doi: 10.2196/17458] [Medline: $\underline{32348289}$ ]

16. Nuamah J, Mehta R, Sasangohar F. Technologies for Opioid Use Disorder Management: Mobile App Search and Scoping Review. JMIR Mhealth Uhealth 2020 Jun 05;8(6):e15752 [FREE Full text] [doi: 10.2196/15752] [Medline: 32501273]

17. Marcano BJS, Huckvale K, Greenfield G, Car J, Gunn LH. Smartphone and tablet self management apps for asthma. Cochrane Database Syst Rev 2013;11:CD010013. [doi: 10.1002/14651858.CD010013.pub2] [Medline: 24282112]

18. Mulvaney SA, Ho Y, Cala CM, Chen Q, Nian H, Patterson BL, et al. Assessing adolescent asthma symptoms and adherence using mobile phones. J Med Internet Res 2013;15(7):e141 [FREE Full text] [doi: 10.2196/jmir.2413] [Medline: 23864345]

19. Kagen S, Garland A. Asthma and Allergy Mobile Apps in 2018. Curr Allergy Asthma Rep 2019 Feb 02;19(1):6 [FREE Full text] [doi: 10.1007/s11882-019-0840-z] [Medline: $\underline{\text { 30712150] }}$

20. Cook KA, Modena BD, Simon RA. Improvement in Asthma Control Using a Minimally Burdensome and Proactive Smartphone Application. J Allergy Clin Immunol Pract 2016;4(4):730-737.e1 [FREE Full text] [doi:

10.1016/j.jaip.2016.03.005] [Medline: 27107690]

21. Harris SK, Aalsma MC, Weitzman ER, Garcia-Huidobro D, Wong C, Hadland SE, et al. Research on Clinical Preventive Services for Adolescents and Young Adults: Where Are We and Where Do We Need to Go? J Adolesc Health 2017 Mar;60(3):249-260 [FREE Full text] [doi: 10.1016/j.jadohealth.2016.10.005] [Medline: 28011064]

22. Rising CJ, Jensen RE, Moser RP, Oh A. Characterizing the US Population by Patterns of Mobile Health Use for Health and Behavioral Tracking: Analysis of the National Cancer Institute's Health Information National Trends Survey Data. J Med Internet Res 2020 May 14;22(5):e16299 [FREE Full text] [doi: 10.2196/16299] [Medline: $\underline{\text { 32406865] }}$

23. Krebs P, Duncan DT. Health App Use Among US Mobile Phone Owners: A National Survey. JMIR Mhealth Uhealth 2015;3(4):e101 [FREE Full text] [doi: 10.2196/mhealth.4924] [Medline: 26537656]

24. Ramsey RR, Plevinsky JM, Kollin SR, Gibler RC, Guilbert TW, Hommel KA. Systematic Review of Digital Interventions for Pediatric Asthma Management. J Allergy Clin Immunol Pract 2020 Apr;8(4):1284-1293. [doi: 10.1016/j.jaip.2019.12.013] [Medline: 31870809 ]

25. Tinschert P, Jakob R, Barata F, Kramer J, Kowatsch T. The Potential of Mobile Apps for Improving Asthma Self-Management: A Review of Publicly Available and Well-Adopted Asthma Apps. JMIR Mhealth Uhealth 2017 Aug 02;5(8):e113 [FREE Full text] [doi: 10.2196/mhealth.7177] [Medline: 28768606]

26. Jácome C, Almeida R, Pereira AM, Araújo L, Correia MA, Pereira M, INSPIRERS group. Asthma App Use and Interest Among Patients With Asthma: A Multicenter Study. J Investig Allergol Clin Immunol 2020 Apr;30(2):137-140 [FREE Full text] [doi: 10.18176/jiaci.0456] [Medline: 32327403]

27. Johnson KB, Patterson BL, Ho Y, Chen Q, Nian H, Davison CL, et al. The feasibility of text reminders to improve medication adherence in adolescents with asthma. J Am Med Inform Assoc 2016 May;23(3):449-455. [doi: 10.1093/jamia/ocv158] [Medline: 26661717]

28. Mosnaim G, Li H, Martin M, Richardson D, Belice PJ, Avery E, et al. A tailored mobile health intervention to improve adherence and asthma control in minority adolescents. J Allergy Clin Immunol Pract 2015;3(2):288-290.e1 [FREE Full text] [doi: 10.1016/j.jaip.2014.10.011] [Medline: 25609351]

29. Real FJ, Beck AF, DeBlasio D, Zackoff M, Henize A, Xu Y, et al. Dose Matters: A Smartphone Application to Improve Asthma Control Among Patients at an Urban Pediatric Primary Care Clinic. Games Health J 2019 Oct;8(5):357-365. [doi: 10.1089/g4h.2019.0011] [Medline: 31157983]

30. Yazdani A, Safdari R, Golkar A, R Niakan Kalhori S. Words prediction based on N-gram model for free-text entry in electronic health records. Health Inf Sci Syst 2019 Dec;7(1):6. [doi: 10.1007/s13755-019-0065-5] [Medline: 30886701]

31. Wu AC. The Promise of Improving Asthma Control Using Mobile Health. J Allergy Clin Immunol Pract 2016;4(4):738-739. [doi: 10.1016/j.jaip.2016.04.003] [Medline: 27393782] 
32. Tatara N, Arsand E, Skrøvseth SO, Hartvigsen G. Long-term engagement with a mobile self-management system for people with type 2 diabetes. JMIR Mhealth Uhealth 2013;1(1):e1 [FREE Full text] [doi: 10.2196/mhealth.2432] [Medline: 25100649]

33. Leigh S, Ashall-Payne L, Andrews T. Barriers and Facilitators to the Adoption of Mobile Health Among Health Care Professionals From the United Kingdom: Discrete Choice Experiment. JMIR Mhealth Uhealth 2020 Jul 06;8(7):e17704 [FREE Full text] [doi: 10.2196/17704] [Medline: 32628118]

34. Adu MD, Malabu UH, Malau-Aduli AE, Drovandi A, Malau-Aduli BS. User Retention and Engagement With a Mobile App Intervention to Support Self-Management in Australians With Type 1 or Type 2 Diabetes (My Care Hub): Mixed Methods Study. JMIR Mhealth Uhealth 2020 Jun 11;8(6):e17802 [FREE Full text] [doi: 10.2196/17802] [Medline: 32525491]

35. Rhee H, Allen J, Mammen J, Swift M. Mobile phone-based asthma self-management aid for adolescents (mASMAA): a feasibility study. Patient Prefer Adherence 2014;8:63-72 [FREE Full text] [doi: 10.2147/PPA.S53504] [Medline: 24470755]

36. Farzandipour M, Nabovati E, Heidarzadeh Arani M, Akbari H, Sharif R, Anvari S. Enhancing Asthma Patients' Self-Management through Smartphone-Based Application: Design, Usability Evaluation, and Educational Intervention. Appl Clin Inform 2019 Oct;10(5):870-878. [doi: 10.1055/s-0039-1700866] [Medline: 31724144]

37. Roberts C, Sage A, Geryk L, Sleath B, Carpenter D. Adolescent Preferences and Design Recommendations for an Asthma Self-Management App: Mixed-Methods Study. JMIR Form Res 2018 Sep 13;2(2):e10055 [FREE Full text] [doi: 10.2196/10055] [Medline: 30684424]

38. Ramsey RR, Carmody JK, Holbein CE, Guilbert TW, Hommel KA. Examination of the uses, needs, and preferences for health technology use in adolescents with asthma. J Asthma 2019 Sep;56(9):964-972. [doi: 10.1080/02770903.2018.1514048] [Medline: 30207802]

39. Geryk LL, Roberts CA, Sage AJ, Coyne-Beasley T, Sleath BL, Carpenter DM. Parent and Clinician Preferences for an Asthma App to Promote Adolescent Self-Management: A Formative Study. JMIR Res Protoc 2016 Dec 06;5(4):e229 [FREE Full text] [doi: 10.2196/resprot.5932] [Medline: 27923777]

40. Hsia BC, Wu S, Mowrey WB, Jariwala SP. Evaluating the ASTHMAXcel Mobile Application Regarding Asthma Knowledge and Clinical Outcomes. Respir Care 2020 Jun 02. [doi: 10.4187/respcare.07550] [Medline: 32487751]

41. Ammari WG, Obeidat NM, Anani AR, AlKalbani RJ, Sanders M. ATTACHED, DETACHED and WITHOUT inhaler technique coaching tools to optimize pMDI use competence, asthma control and quality-of-life in asthmatic adults. J Thorac Dis 2020 May;12(5):2415-2425 [FREE Full text] [doi: 10.21037/jtd.2020.03.50] [Medline: 32642147]

42. Horwitz D, Kestenbom I, Goldbart A, Chechik T, Dizitzer Y, Golan-Tripto I. The effect of a coaching program on asthma control and health care utilization in children with asthma. J Asthma 2019 Oct 08:1-8. [doi: 10.1080/02770903.2019.1672721] [Medline: $\underline{31591919}$ ]

43. Hamari J, Koivisto J, Sarsa H. Does Gamification Work? -- A Literature Review of Empirical Studies on Gamification. New York: IEEE; 2014 Presented at: 2014 47th Hawaii International Conference on System Sciences; January 6-9, 2014; Waikoloa, HI p. 3025-3034 URL: https://people.uta.fi/ kljuham/2014-hamari et al-does gamification work.pdf [doi: 10.1109/hicss.2014.377]

44. Edwards EA, Caton H, Lumsden J, Rivas C, Steed L, Pirunsarn Y, et al. Creating a Theoretically Grounded, Gamified Health App: Lessons From Developing the Cigbreak Smoking Cessation Mobile Phone Game. JMIR Serious Games 2018 Nov 29;6(4):e10252 [FREE Full text] [doi: 10.2196/10252] [Medline: 30497994]

45. Rudin RS, Fanta CH, Predmore Z, Kron K, Edelen MO, Landman AB, et al. Core Components for a Clinically Integrated mHealth App for Asthma Symptom Monitoring. Appl Clin Inform 2017 Oct;8(4):1031-1043 [FREE Full text] [doi: 10.4338/ACI-2017-06-RA-0096] [Medline: 29241243]

46. Dennison L, Morrison L, Conway G, Yardley L. Opportunities and challenges for smartphone applications in supporting health behavior change: qualitative study. J Med Internet Res 2013;15(4):e86 [FREE Full text] [doi: 10.2196/jmir.2583] [Medline: 23598614]

47. Mercer K, Li M, Giangregorio L, Burns C, Grindrod K. Behavior Change Techniques Present in Wearable Activity Trackers: A Critical Analysis. JMIR Mhealth Uhealth 2016;4(2):e40 [FREE Full text] [doi: 10.2196/mhealth.4461] [Medline: 27122452]

48. Al-Durra M, Torio M, Cafazzo JA. The use of behavior change theory in Internet-based asthma self-management interventions: a systematic review. J Med Internet Res 2015;17(4):e89 [FREE Full text] [doi: 10.2196/jmir.4110] [Medline: 25835564]

49. Gibbons J, Malouf R, Spitzberg B, Martinez L, Appleyard B, Thompson C, et al. Twitter-based measures of neighborhood sentiment as predictors of residential population health. PLoS One 2019;14(7):e0219550 [FREE Full text] [doi: 10.1371/journal.pone.0219550] [Medline: 31295294]

50. Mammen JR, Java JJ, Rhee H, Butz AM, Halterman JS, Arcoleo K. Mixed-methods content and sentiment analysis of adolescents' voice diaries describing daily experiences with asthma and self-management decision-making. Clin Exp Allergy 2019 Mar;49(3):299-307. [doi: 10.1111/cea.13250] [Medline: 30113733]

51. Liu J, Davidson E, Bhopal R, White M, Johnson M, Netto G, et al. Adapting health promotion interventions to meet the needs of ethnic minority groups: mixed-methods evidence synthesis. Health Technol Assess 2012;16(44):1-469 [FREE Full text] [doi: 10.3310/hta16440] [Medline: 23158845] 
52. Liu S, Chen B, Kuo A. Monitoring Physical Activity Levels Using Twitter Data: Infodemiology Study. J Med Internet Res 2019 Jun 03;21(6):e12394 [FREE Full text] [doi: 10.2196/12394] [Medline: $\underline{\text { 31162126] }}$
Abbreviations
mHealth: mobile health
NAEPP: National Asthma Education and Prevention Program

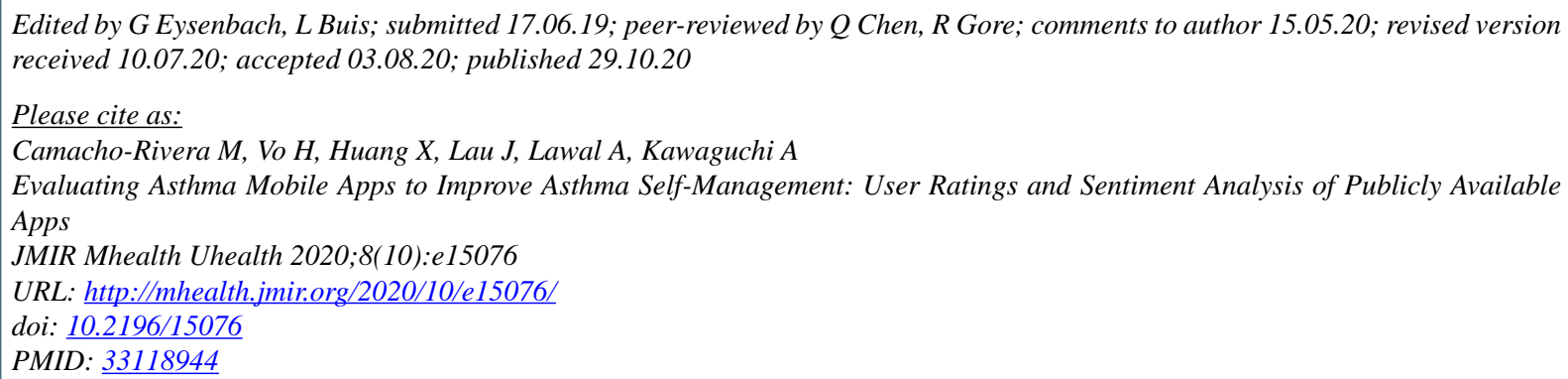

(CMarlene Camacho-Rivera, Huy Vo, Xueqi Huang, Julia Lau, Adeola Lawal, Akira Kawaguchi. Originally published in JMIR mHealth and uHealth (http://mhealth.jmir.org), 29.10.2020. This is an open-access article distributed under the terms of the Creative Commons Attribution License (https://creativecommons.org/licenses/by/4.0/), which permits unrestricted use, distribution, and reproduction in any medium, provided the original work, first published in JMIR mHealth and uHealth, is properly cited. The complete bibliographic information, a link to the original publication on http://mhealth.jmir.org/, as well as this copyright and license information must be included. 